\title{
Ses ThelTLAS \\ From Discipline to Inter-and Transdiscipline in the Environmental Academic Sector in Mexico
}

\author{
María Concepción Martínez Rodríguez, Luis Ángel Jiménez López and Omar Mayorga \\ Pérez, Centro Interdisciplinario de Investigaciones y Estudios sobre Medio Ambiente y Desarrollo (CIIEMAD) Instituto \\ Politécnico Nacional (IPN), Del. Gustavo A. Madero, México, D.F. MEXICO. Emails: mconcepcionmr@yahoo.com.mx and \\ mcmartinezr@ipn.mx
}

Received 20 November 2017; Revised 18 December 2017; Accepted 25 December 2017

Copyright (C) 2017 María Concepción Martínez Rodríguez, Luis Ángel Jiménez López and Omar Mayorga Pérez. This is an open access article distributed under the Creative Commons Attribution License (https://creativecommons.org/licenses/by/4.0/), which permits unrestricted use, distribution, and reproduction in any medium, provided the original work is properly cited.

Available online 30 December, 2017 at www.atlas-journal.org, doi: 10.22545/2017/00090

\begin{abstract}
$n$ the present work we outline the history of
environmental policy and institutions through a
timeline, in which we observe the advances that Mexico has made in this area, some of them due to international situations. The response to these obligations requires the training of specialists in the subject, who will advance from a purely sectorial (disciplinary) vision through multidisciplinary work to a transversal (transdisciplinary) conception, at least on paper. However, this was not possible due to the priorities of the Mexican governments of the twentieth century, now it is proposed to move towards this interdisciplinary work in the environmental sector through a series of policies whose results are shown, through an exploratory deductive study.
\end{abstract}

Keywords: Transdisciplinarity, Mexico, En- vironmental Sector, sustainability, education.

\section{Introduction}

During the 1800s, the Mexican territory was composed of 5 million $\mathrm{km}^{2}$ with a population of 5 , 837,100 inhabitants, reaching from the Isthmus of Panama on the South, to Oregon on the North. Due to the political instability in the country, more than $60 \%$ of the territory was lost, currently the area is $1,964.375 \mathrm{~km}^{2}$ with a population of $112,106.672$ inhabitants. This leads us to reflect that more natural resources are lost through politics than through natural phenomena, not only in Mexico's past but also in its present [1]. In this paper we have decided to contextualize the discipline, interdiscipline and transdiscipline through the evolution of the envi- 
ronmental policy and institutionalism in Mexico, as well as the study of the incorporation of environmental issues in the universities of the country and the advances in interdisciplinary work. The above is exemplified with an interdisciplinary center and its academic activities in the environmental sector as a result of the orientation of policies in science and technology.

\section{Historical Overview of the Environmental Research in Mexico}

The environmental sector in the history of ancient Mexico is shown as a harmonious and respectful relationship through the poems of Nezahualcóyotl, King (tlatoani) of Texcoco in 1402. The knowledge that the ancient inhabitants of Mexico had are as different as astronomical, agricultural, commercial and architectural, which allowed the construction of aqueducts, botanical gardens, agricultural cycles among others; during and after the conquest of Mexico by the Spaniards. The management of natural resources was carried out through the ordinances of the Motherland, which referred to the measured use by the locals, in contrast to the exploitation and export by the Spaniards. Among the professions that arrived together with Hernán Cortés, which impacted because of their activities, were: the founding doctors of the task of public and private health, the religious who were in charge of the evangelization of the natives, the foundation of art and trades schools and the clerical, the miners who made the first expeditions to the volcanoes and mountains for the extraction of minerals, and the lawyers and administrators who came from the schools of Salamanca, Valladolid or Alcalá [2] [3].

The Spanish Crown created the Royal and Pontifical University of Mexico by Royal Decree on September 21, 1551 and the organization of knowledge in the colonial University followed the traditional model of European medieval universities: with four major faculties which are Theology, Canons, Laws and Medicine and a minor Arts. There they were formed, especially clerics and also the members of the incipient New Spain bureaucracy. At the end of the 18th century, the Mining College and the Botanical Garden (1772) were created. When the Independence was achieved, the schools of San Ildefonso, San Gre- gorio, San Juan de Letrán y Minería, the School of Medicine, the San Carlos Academy and the Military School emerged [4] [5].

Because of the nascent university, the conditions were created to form a minority of literate able to perform the middle positions of the state and ecclesiastical bureaucracy, instead of the Creoles having to go to Spain to obtain such training, or that, due to the lack of qualified personnel in Mexico for such administrative positions, all of them had to be provided from Spain, and with individuals of peninsular origin [5].

After the Independence of Mexico (1810) and the readjustments of a new nation, the Superior Health Council was created in 1841, which consisted of five full members: three were doctors, one a pharmacist and one a chemist. Its task was to monitor the correct practice of medicine and pharmacy, to carry out health actions for the benefit of the population and to carry out studies of various epidemics and mortality statistics. Likewise, it was in charge of legislating the surveillance of cemeteries, schools and workshops, said council was attached to the Ministry of Health [6].

The evolution of the environmental policy in Mexico was taking place as the country developed in its economic activity, in its population increase and in international demands. Initially, its focus was purely health, in charge of health professionals, whose approach to knowledge was to improve the sanitary conditions of the natural environment of the population, while continuing to exploit natural resources for export. It was in 1917 when the environmental policy was written for the first time in the Constitution of the United Mexican States; it was determined that ownership of land and water belonged to the nation and that public interest was above private property. Another important aspect of this was the distinction between the soil and the subsoil, which resumed the dominance of the subsoil for the nation [7] [8].

The professions that were added to address the environmental issue, apart from doctors, chemists, pharmacists, were lawyers and economists; with the issuance in 1940 of the Regulation for commercial, annoying, unhealthy or dangerous industrial establishments. This regulation was directed mainly to the industrial sector, which had a great support for its development, however, it had already become clear the pollution that this sector generated, rea- 
son why this regulation prohibited the discharges of industrial waste hazardous for humans, animals and agriculture, required in industrial establishments to treat substances in order to control emissions into the atmosphere. The above said regulation was issued by the Ministry of Economy.

In 1940, Mexico joined the Convention for the Protection of Nature and Preservation of the Wildlife of the Western Hemisphere. As a result, a series of regulatory guidelines was created, including the Forestry Law and the Law on Soil Conservation and Water (the latter being the first of its kind in Mexico, where it was expressly stated that prevention of soil erosion and flooding was of public interest). In 1947 there was a reform of the Forest Law where forest reserves and protected areas in the hydrological basins were established to protect the irrigation and electric power systems, decreeing total bans in the forests of the center of the country to guarantee their recovery. In this stage the professionals who took rise in the environmental sector were the agronomists who left the common pattern of going to train in France or European schools and went to the United States to learn techniques of soil conservation, a priority that had been set government.

From 1969 the environmental legislation focused on the prevention of pollution, promulgating among the regulatory framework the Federal Law to Prevent and Control Environmental Pollution, the Regulation for the Prevention and Control of Atmospheric Pollution originated by fumes and dust, the Regulation for the Control and Prevention of Water Pollution, Regulation to Prevent and Control Sea Pollution by Dumping Waste and other Materials. The professionals involved in the growing regulation were civil engineers, chemists, hydraulics, foresters, agronomists, biologists, lawyers, economists, architects and urban planners [8] [9] [10].

In 1972, the United Nations Conference on the Human Environment, held in Stockholm, Sweden, was convened by the United Nations Organization; It was the first major conference on international environmental issues, and marked a turning point in the development of international environmental policy; as the way to analyze environmental problems from an interdisciplinary perspective.

For Mexico, it influenced the creation of environmental institutions such as the Under secretariat for the Improvement of Environment, which would address environmental issues, with a priority to address pollution problems, the creation of the General Directorate of Urban Ecology (1976), the Inter ministerial Commission for Environmental Sanitation (1978), Ministry of Fisheries and the Secretariat of Urban Development and Ecology SEDUE (1983), with professionals in the different branches of engineering in the different institutions. In 1987 the meeting of the World Commission on Environment and Development of the United Nations was held and the report "Our Common Future", better known as the Brundtland Report, was published. The document suggests that countries should adopt population control measures, guaranteeing basic health, education and housing needs; food safety; access to drinking water and sanitation; conservation of biodiversity and the reduction of fossil fuel consumption, encouraging the adoption of renewable energy sources [8] [11]. In response to the Brundtland Report, Mexico issues the General Law of Ecological Equilibrium and Protection of the Environment, LGEEPA (1988), which makes a competent distribution of environmental matters between the federal government, state entities and municipalities. It is situated beyond the environmental notion as a problem of pollution which poses it as a problem of natural resources, its proposal is that of an integral perspective, it appeals to the environment and its multiple interconnections with factors of natural order and social nature [8]. In the first instance, a multi-institutionalmultidisciplinary participation is sought to address the environmental sector.

In 1988 the Intergovernmental Panel on Climate Change (IPCC) was created to provide comprehensive assessments of the state of scientific, technical and socio-economic knowledge on climate change, its causes, possible impacts and response strategies. Among the professional participants who had been participating in the environmental sector were physicists, sociologists, geologists, geophysicists, oceanographers, to provide disciplinary options against the phenomenon of climate change.

In 1992, the United Nations Conference on Environment and Development was held in Rio de Janeiro, Brazil, and in Mexico the National Institute of Ecology was created as the institution that would address the environmental issue as a whole and be able to issue the policy for Mexico, with the support of the Federal Environmental Protection Agency (PROFEPA), which would monitor compliance with this environmental policy. Also in 1992, 
in addition to INE and PROFEPA, CONABIO, the National Commission for the Knowledge and Use of Biodiversity, was created. The professionals who headed these dependencies were biologists, with international postgraduate degrees, some of them in ecology.

In 1994, with the signing of the North American Free Trade Agreement (NAFTA) and the entry of Mexico into the Organization for Economic Cooperation and Development (OECD), there was a strong increase in the country's economic activity. creation of institutions equivalent to those of their counterparts, for example the Secretariat of the Environment, Natural Resources and Fisheries (Semarnap) was created, led by a biologist whose mission was to raise the range of the national environmental policy by bringing together various bodies with environmental attributions In a single secretariat and incorporating the notion of sustainable development, it was constituted as the authority in environmental matters with competence in water, hunting, fishing, air, forests and environmental issues in general. The INE became his intellectual arm where academics began environmental research.

In 1996, the LGEEPA was reformed, where environmental legal aspects were incorporated, adding self-regulation, voluntary environmental audits, inventories of pollutant releases and transfers and the unification of procedures for operation and functioning of labor competency establishments. It incorporated guidelines derived from international conventions and adscription to international institutions such as the OECD and the term: the polluter pays, it also include economic instruments and decentralization. It let the environmental policy had a selfmanagement approach to encourage the industrial sector to comply, so the professionals in the industries were in charge of the departments of Safety and Hygiene who handled everything related to the environmental sector, most of them were mostly engineers who received complementary training in the environmental area, through courses and diplomas. After Mexico signed the United Nations Framework Convention on Climate Change (UNFCCC) in 1992 as part of the agreements, in 1997 Mexico's first national communication on climate change was released. It consisted of an emissions inventory of greenhouse gases of 1990 and the first studies of the country's potential vulnerability to climate change. With the above, Mexico began to change its envi- ronmental policy, orienting it towards the demands of the international climate change policy. On June 9, 1998, Mexico signed the Kyoto Protocol, and the Senate of the Republic approved its ratification on April 29, 2000 [11].

The Semarnap in 2000 changes to Semarnat (Secretariat of Environment and Natural Resources) with three undersecretaries:

1. Planning and environmental policy.

2. Management for environmental protection.

3. Fomento a la normatividad ambiental.

Institutions are created for environmental control:

1. National Forestry Commission (CONAFOR) 2001.

2. National Institute of Forestry, Agriculture and Livestock Research (INIFAP), 2001.

3. National Commission of Natural Protected Areas (CONANP) 2002.

4. Interministerial Commission on Climate Change (CICC) 2005.

Although the dependencies are headed by disciplines such as biology, it is a fact that with the creation of different institutions the integration of several disciplines was sought, an interinstitutionalinterdisciplinary work is attempted, between the disciplines of the natural sciences and the disciplines of the social sciences; the reflection would lead us to think that if Mexico had had interdisciplinary personnel in the environmental sector, it would not have led to the creation of multiple environmental dependencies that duplicate functions and atomize resources.

In 2001, reforms were made to the LGEEPA in relation to the construction of the program to promote Sustainable Development in the Federal Government, the Transversality Agendas of Public Policies for Sustainable Development are made. Collaborating with: the Secretariat of Agrarian Reform (SRA), the Secretariat of Agriculture, Livestock and Rural Development (SAGAR), the Secretariat of Communications and Transportation (SCT), the Secretariat of Economy and Industrial Development (SECOFI), the Secretariat of Social Development (SEDESOL), the Ministry of Public Education (SEP) and the Ministry of Health (SS). 
This represented a great advance for the environmental sector, the institutional proposal of transversality, invited Mexico to respond with its social capital to transdisciplinary works. In 2002 the Johannesburg Summit was held in South Africa, it was a meeting where the determination to work towards sustainable development was reaffirmed. Where the priority measures required for sustainable development were established, encouraging governments, civil society and companies to present initiatives to establish collaboration agreements to improve the living conditions of people around the world [11].

As a result of this meeting there were advances and modifications in the regulatory framework of the environmental sector in Mexico, including the LGEEPA (it modified articles 19 on the territorial ordering of human settlements and their natural environment, environmental impact, Art. 51 related to the Areas Protected Naturals), and the 20072012 Sectorial Program for Environment and Natural Resources (PSMARN) was created, which establishes the set of sectoral, strategic objectives and goals through which the sector will meet the objectives and strategies defined by the National Development Plan in Environmental Sustainability, which was distinguished as a fundamental axis in sustainable human development.

The current 2013-2018 National Development Plan stands out for the recognition of the need for joint actions and commitments between the different levels of government and for the objectives of environmental preservation; however, it is worrisome that the concept of sustainable development has disappeared. As of 2012, the environmental policy was subscribed to the attention of the agreements of the United Nations Conference on Climate Change, the General Law of Climate Change was issued, published on June 6, 2012; the National Communications of Mexico on Climate Change are issued where the national inventories of greenhouse gas emissions are updated, the scope of the General Law of Climate Change is specified, and the advances of the programs to mitigate climate change and in the integration of the topic of climate change in the social, environmental and economic policies of Mexico. The participation of the professionals is based on the adaptation of the methodologies issued internationally for the measurements of greenhouse gases through mathematical modeling of atmospheric and maritime processes that represent in graphical forms the increase in tem- perature, the increase in the level of the sea, etc., at first the physicists, geophysicists, meteorologists, have displaced the other traditional professionals, leaving the social sciences far behind in their various disciplines facing the study of environmental policy and climate change.

"Rio +20 " is the abbreviated name of the United Nations Conference on Sustainable Development, held in Rio de Janeiro, Brazil (June 20-22, 2012), twenty years after the historic Earth Summit in Rio in 1992. Rio +20 , the world leaders, together with thousands of participants from the private sector, NGOs and other groups, came together to shape the way in which it can reduce poverty, promote social equity and guarantee the protection of the environment on an increasingly populated planet. The two main themes were: how to build an ecological economy to achieve sustainable development and lift people out of poverty, and how to improve international coordination for sustainable development.

The Mexican environmental policy has been blurred to move from a national policy to an international policy, framed by all those international demands on measurement, mitigation, vulnerability to the phenomenon of climate change; everything that had been gained within the federal public administration on discipline, multidisciplinary, interdisciplinary, institutional trans-disciplinary environmental sector, even on paper, is falling into an inaccuracy of responsibilities between international agencies and national government, a situation that could certainly leave local environmental issues aside.

As a conclusion to this first part we could say that the answer in question of trained human resources for the environmental sector was exceeded, with the institutional changes in the sector, from the 19th century until the end of the 20th century, it was tried to follow up with professional disciplines, initially trained in European schools, until Mexico was able to create its own human resources. However, always behind the progress that was made in the construction, modification, institutional innovation in this sector, partly driven by international agreements; undoubtedly, it was an opportunity for the academic sector from the universities to grow and respond to these advances. However, this was not the case, the lack of human resources prepared in the sector has led Mexico to take wrong decisions. We dare to say that the lack of trained personnel allowed the privatization of the environmental sector, 
leaving the responsibility of environmental policy to international organizations.

\section{The (Tardy) Response of the Academy to Changes in the Environmental Sector}

The different stages through which Mexico passed through during the nineteenth and twentieth centuries, tell us about a process based mainly on the exploitation of natural resources, the industrialization of the country, and the creation of institutions and universities, to achieve a "stabilizing development".

The changes in the population of our country with accelerated growth, the urbanization process, protectionism and the policy of import substitution meant that in less than 30 years the country went from being predominantly agricultural and rural to being industrialized and urbanized.

Within its system of higher education, the university, which could be considered modern, was founded in Mexico. In 1551, when the National University of Mexico was opened, several of the existing schools (located in Michoacán, Yucatán, San Luis Potosí, and Guadalajara) were incorporated to the University that in this way became the main training institution for professionals. As of 1916, several Technical Education Schools were created that depended on the Secretary of Public Education that culminated in the founding of the National Polytechnic Institute (1936). In 1948 the Regional Technological Institutes were founded. Thus, the aforementioned institutions, together with private institutions, are part of Mexico's higher education system and are in charge of training the professionals in demand for the development of the country; however, this system in the public sector continued to operate until past the mid-twentieth century with the same programs with which they were created, without curricular updates, representing a delay in their programs compared to the demands and requirements of the country. It gives the impression that the rulers thought that sowing educational institutions throughout the country was enough and that these alone were going to be renewed and were going to be generating knowledge and professionals at the same time that the country was growing. At the beginning of the sixties there was an educational impulse, to call it somehow, by President López Mateos, with the creation of a financing and subsidy policy to the UNAM and the Universities of the States. However in the following administration Chaired by Gustavo Diaz Ordaz (1964-1970) priorities changed as well as the way to exercise power. For him, the educational institutions represented a great budgetary burden and a benefit that had to be revised because it could not be for the whole population, so the decrease in financing to the universities began.

The Mexican universities are a sample of how the backwardness in the economy and the petty interests of the class of an oligarchy are reflected in the culture of the country in question. Our universities, many of them with great and ancient traditions have evident lack of the elements essential for any university due to the scarcity of budgetary resources and the existing disorder [12].

The authoritarian government did not accept the demands of the middle class to participate in the political life of the country, the abandonment of higherlevel schools (low salaries to teachers, no scientific research, deterioration of infrastructure) political control of workers, peasants and workers in general, through anti-democratic and intolerant corporate organizations, non-existent freedom of expression and press, among other characteristics, made it possible for the university to become an alternative political space for the democratic struggle. Indeed, the universities, sheltered in the autonomy (product of the anti-authoritarian struggles against the Mexican State of the Thirties), were practically the only social space where dissidence and free thought could be expressed [12].

The promises that had been made after the Mexican Revolution of 1910 were forgotten, followed by inequality, misery, insalubrity, ignorance, injustice, all wrapped up in an apparent development of the country. Towards the end of the 1960s, universities had their lowest level of relationship with the State. They were socially recognized as a problematic focus, they had become the alternative spaces of response to the regime, they did not enjoy finances that allowed them to develop and expand according to the pressures of student demand, and the above is culminated with the Tlatelolco massacre, where the official repression reached limits never seen before.

During the presidency of Luis Echeverría Álvarez (1970-1976), the situation returned to an apparent calm. The conditions for a general process of modern- 
ization of higher education weregiven with the aim of "healing their wounds" [5]. New schools werecreated within the two largest public universities in the country, for two reasons: because of demand and as a strategy for the rigidity to change existing schools; in the National Autonomous University of Mexico: the Colleges of Sciences and Humanities (CCH's) and the National Schools of Professional Studies (ENEPs); within the National Polytechnic Institute is created the Interdisciplinary Professional Unit of Engineering, Social and Administrative Sciences (UPIICSA), and the Interdisciplinary Center of Health Sciences (CICS), as well as in the subsequent years the Interdisciplinary Research Centers for Integral Development Regional in Durango, Michoacán, Oaxaca (1980); the Interdisciplinary Center for Research and Studies on Environment and Development (CIIEMAD) (1996), the Interdisciplinary Professional Unit of Biotechnology UPIBI (1987) and the Interdisciplinary Professional Unit of Engineering and Advanced Technology UPIITA (1996).

Other of the higher level institutions that were created wasthe Colegio de Bachilleres and the Universidad Autónoma Metropolitana (UAM) (1970's).

This reform in higher education had an emphasis on transforming existing disciplines or creating new disciplines through systematized and permanent making of research tasks. As a result of this modernization, the range of careers related to the environment was expanded, such as: Environmental Engineering, Energy Resources Engineering, human settlements design, hydrological engineering, mechanical engineering, electrical engineering, industrial engineering, bioengineering, social anthropology, biomedical engineering, physical engineering, metallurgical engineering, chemical engineering, hydrobiology, experimental biology, animal production, among others that being traditional careers were given novel approaches with the insertion of subjects that had an interdisciplinary focus [12].

Since 1970 the ANUIES (National Association of Universities and Institutions of Higher Education) postulated Interdisciplinarity as an alternative to renew the fields of knowledge, to build a new dialogue between disciplines to efficiently solve research problems and to articulate a constructivist perspective to knowledge and school learning. This Interdisciplinarity required a new organizational structure, but above all a deep revision of the division of academic work; although modernization led to the opening of new academic offerings, interdisciplinarity was mentioned in paper and in the objectives to be achieved throughout the higher education system, its results in these years were meager.

Decisions in general in the environmental sector of Mexico during the 20th century were taken unilaterally by governments (bureaucrats with traditionalist formations of lawyers, administrators, doctors, accountants, biologists, etc.), democratization in the environmental sector changes with the modernization of higher education where the academic sector begins to play with the creation of professions related to the environmental sector and the modification of traditional careers approaches.

There are currently 1200 academic programs nationwide on environmental issues although most of them are based on natural and exact sciences, with a reductionist vision in the search for solutions.

In the National Polytechnic Institute, the second largest and oldest public university in Mexico, the following strategy was presented: creation of new careers related to the environmental sector, updating of the programs of traditional careers including subjects related to environmental pollution, ecology, and environment. It also created Research Centers that will address the environmental issue in an interdisciplinary manner and create a postgraduate division that will encourage work in research networks, thus bringing together researchers from different schools to work jointly on postgraduate research and training projects. Within this program is the Environment Network and the Economic Development Network, which in an interdisciplinary way works for innovation in the postgraduate course [13].

Currently the National Polytechnic Institute has the following academic offers related to the environmental sector and the discipline, multidisciplinary and interdisciplinary [14]:

At the technical level: we have two clearly environmental careers such as: Technician in Ecology, Technician in Diagnosis and Environmental Improvement, and in 9 we have incorporated environmental matters such as: industrial safety and environmental impact, environmental impact in public and private sector projects, sustainability of plastics, control and elimination of hazardous waste, control and disposal of chemical waste, solution to an environmental problem, effects of contaminants on health, control and elimination of hazardous waste, sustainable development. 
At the Bachelor's level: we have two streams of environmental engineering: Engineering in Environmental Systems and Environmental Engineering. And among the 21 types of engineering and 10 bachelor's degrees there are about 58 subjects, either compulsory or optional with environmental training: Sustainable development, environmental geophysics, sustainable development, climatology and climate change, environmental management, environmental engineering, cleaner production, natural resources and sustainable development, alternative energies, environmental engineering, environmental administration and management, sustainable social housing, landscape architecture, environment and city architecture, sustainable buildings and recycling of buildings, management and management of green areas, environmental assessment and sustainable development, sanitary engineering and environmental, water quality and contamination of water bodies, design construction and monitoring of sanitary landfills, drainage and landscape, integral management of watersheds, environmental geology and geological risk, basin analysis, characterization and remediation of contaminated sites, legal foundations of geoenvironmental management, assessment of aquifers, environment, environmental management and clean technologies, recycling technology, energy and environmental chemistry, risk planning and environmental impact, treatment and remediation of waste from the food industry, environmental protection, automotive environmental engineering, technology environmental clinic, ecology, environmental audit, tourism and the environment, environmental management system for tourism, management of sustainable tourism, industrial safety and environmental systems, environmental planning and management, natural and cultural diversity of Mexico, environmental planning and evaluation in Mexico, innovation and sustainable initiatives.

And at the graduate level we have multidisciplinary and interdisciplinary areas: which includes four doctorates in environmental science. Doctorate in Sciences in Agroecological Management of plagues and diseases, Doctorate in Sciences in Conservation of the Landscape Patrimony, Doctorate in Sciences in Fish and Aquaculture Bioeconomy, Doctorate in Marine Sciences.

10 master's degrees: Master of Science in Sustainable Agricultural Production, Master of Science in Environmental and Sustainability Studies, Master of Environmental Management and Audits, Master of Engineering in Cleaner Production, Master of Marine Resource Management, Master of Business Administration for Sustainability, Master of Science in Environmental Management, Master's Degree in Geosciences and Natural Resources Administration, Master's Degree in Project Management for Solidarity Development (With Professional Orientation), Master of Science in Conservation and Exploitation of Natural Resources.

1 specialty: Specialty in Management of Coastal Environments.

2 courses of specific purpose (the courses offered to the general public): The environmental complexity of the city, Epistemology of environmental complexity in urban studies.

Besides the 9 doctorates and 24 disciplinary, multidisciplinary and interdisciplinary master's degrees we have offered 33 optional subjects Environmental biotechnology and sustainable resource management, health ecology, Mexico's biodiversity and sustainable development, environmental biotechnology, industry and its impact on the environment, social architecture and sustainability, safe and sustainable housing, society and climate, environmental physics in buildings, sustainable architecture: current scenarios, selected topics of environmental systems, energy and sustainability, environmental impact of energy systems, competitiveness and sustainability in companies and organizations, environmental economics, experimental methods in environmental chemical engineering, environmental engineering, natural environments, ecosystems and tourism, environmental management for tourism, environment and tourism, formulation and social, economic and environmental evaluation of projects, development, sustainable development and innovation, educational management and sustainable development, development and sustainability, rural and sustainable projects, sustainable innovation, product input and environmental accounts, sustainable regional development, physical oceanography, environmental modeling.

The above mentioned offers that are prevailing in the National Polytechnic Institute even now in 2017, still there is a strong tendency to discipline in the area of higher education and attention to the first stage of environmental problems: such as pollution, At the graduate level the multidisciplinary and interdisciplinary words are observed for a holistic approach. The "delay" or lag in the educational sector, 
especially at the higher education system in Mexico, is due to the country's development demanded the environmental sector and its direct relationship with the options based on the priorities (or long or short term visions, beliefs, customs, preparation, ideologies, political parties, etc.) of the votes (we have not yet developed our democracy for the important decisions fall on the independent society of the colors of which the sexennial transgressors). The rise and subsequent abandonment of higher education over 50 years brought the lack of national human resources that can make decisions on the direction of the environmental sector and the country in general. Innovative modernizing proposals based on the interdisciplinary work that was proposed in the decade of the 70's provided an advance, but it was not enough since there are pending works in the interdisciplinary area of the academy.

Currently, work is being carried out at the graduate level to include Interdisciplinarity in scientific research, master and doctoral programs. In the present work we highlight the effort that has been taking place since the 80 's which brought together the environmental sector and interdisciplinary work.

\section{Sustainability from the Interdiscipline in Mexico}

Currently Mexico has several educational centers that have been born from the idea of Interdiscipline and Multidiscipline, in which many of them were created by institutions of higher education such as the National Polytechnic Institute (IPN) and the National Autonomous University of Mexico (UNAM), in the eighties. Regional Center for Multidisciplinary Research (CRIM) by UNAM in 1983, which aimed to create a space for collaboration between different disciplines, including social, humanistic and scientific, in the approach of objects and research topics directly linked to the problem of the social reality of our country is an example for this [15].

On the other hand, the IPN was chosen for the creation of a master program that would responsible for the training of human resources capable of addressing the problems in Mexico and the region as a result of a call made by the United Nations Environment Program (UNEP) in 1982. In subsequent meetings steered in the cities of Morelia and Morelos, the design of Latin American academic space for the formation of high-level human resources was discussed which would be, responsible for forming a scientific and technological structure and proposing appropriate solutions for the environmental and social conditions of the region and at the national level. That was how the Master's Degree in Environment and Integrated Development (MADI) was born. In August 1984 academic and scientific cooperation between the IPN and the University of Paris III, Sorbonne-Nouvelle de France, began to somehow complement the efforts made with the MADI, by proposing a doctorate in continuity with the proposal to study for two years in the IPN and conclude at the University of Paris III. Derived from the same, the MADI project is changed as the Interdisciplinary Project on Environment and Integrated Development (PIMADI). It is important to note that although there was little background in the approach to environmental problems from academia in Latin America at that time., the program, which was the result of an original idea, was internationally accepted as the environment should be considered as the interrelation of society and nature, so it was considered the training of specialists who would conduct studies through research of an interdisciplinary nature, The highly qualified academic staff in various areas of knowledge, such as earth sciences, social and economic sciences, physical sciences math, biological sciences and engineering were require to participate among others to make this interdisciplinary study. Under the international context of the United Nations Conference on Environment and Development on 1992, in Rio de Janeiro, Brazil, which resulted in the publication of the "Agenda 21", the IPN faced changes., it demanded the constant advancement of knowledge that preserves and increases its results with better criteria and standards of generalizations, as well as it sought to direct its efforts to satisfy the demand for training and research spaces in the field of environment and development., In correspondence with this, their projects of greater importance for the benefit of society was expanded with the sectoral programs of education, environment, science and technology, energy and transport in accordance with the institutional development program 1995 - 2000. The H. Consultive General Council of the IPN, in its Tenth Ordinary Session, held on October 31, 1996, authorized the agreement establishing the Interdisciplinary Center for Research and Studies on Environment and Development (CIIEMAD), having as a platform, the patrimony until then attributed 


\section{to PIMADI.}

This agreement by which the CIIEMAD was established, was published in the Polytechnic Gazette, in number 382, year XXXII, volume 1, on December 15, 1996, its first article to the letter says: “... so that Through its educational processes and the implementation of interdisciplinary scientific and technological research projects, develop and promote harmony between economic growth and sustainable development for the benefit of our country" [16].

The CIIEMAD can be considered as the space offered by the IPN in terms of environment and development, under an innovative interdisciplinary work model that has been operating for 35 years. Currently the CIIEMAD has 34 teachers, 26 doctors and 8 masters in science, with disciplinary training at the undergraduate level (chemical engineering, civil engineering, biology, sociology, anthropology, geology, economics) and with disciplinary and multiinterdisciplinary training at the Master's degree and doctorate (master's degree in environmental engineering, doctorate in chemistry, doctorate in Latin American studies, doctorate in public policies, doctorate in urbanism, etc.) with national and international studies. There are two programmes:

Master of Science in Environmental and Sustainability Studies (incorporated into the national graduate programs of quality of CONACYT, previously was the Master's Degree in Environment and Integrated Development).

Doctorate in Sciences in Conservation of Landscape Heritage (This program is found in the national graduate programs of quality of CONACYT, and is the result of the work of the research networks that formed the IPN, to promote interdisciplinary work in the postgraduate program, CIIEMAD is a node of this doctorate).

There were two more programs, which were declared in recess for their limited possibilities to comply with the guidelines of the CONACYT programs:

Doctorate in Environment and Integrated Development and the Master in Environmental Management and Audits, which operated online in agreement with the Ibero-American University Foundation (FUNIBER).

The CIIEMAD has tried to maintain the offer of a globalizing knowledge more applicable to the solution of environmental problems with a perspective of sustainable development through an inter and transdisciplinary approach.
Its main lines of research are divided into three departments (Table 1). Under this scheme of departmental organization some of the projects that have been developed are shown in Table 2. The offer of elective courses in CIIEMAD are shown in Table 3.

In its enrollment the CIIEMAD can locate students of diverse disciplines interested in environmental aspects and finding different visions to approach the same object of study; among the latest thesis topics that have been handled in the Master of Science in Environmental Studies and Sustainability, the current Master's program of CIIEMAD, are (Table $4 \& 5)$ :

The behavior of the enrollment in this program since 2010, when it was updated, is shown in Table 6.

Among the main problems faced by the CIIEMAD, in its day-to-day activities, are the disciplinary limitations from design and delivery of a subject, the composing of work teams for the construction of a thesis and the frequent loss of the holistic approach to environmental problems. It's worth mentioning that new hires lack of collective memory of the spirit of creation of CIIEMAD, were they only seem to perceive CIIEMAD and IPN as a source of income.

Interdisciplinary work is sometimes complicated by the policies dictated by the National Council of Science and Technology (CONACYT) at the national level on the productivity of teachersresearchers and distinctions to graduate programs. It has created a work dynamic that increasingly distances the teacher from teaching and the researcher brings it closer (restricts) towards lines that CONACYT has established, considering that for the evaluation both the researcher and the programs have a limited margin to expand his investigations for the risk of leaving outside the lines of investigation declared, since the "non-disciplinary" is perceived as something residual, outside the "normal" science. Interdisciplinarity is observed as something not normal, unstable and without coherence, so the challenges faced by Interdiscipline for its development in Mexico can said to be structural, cognitive and normative. CONACYT is the public institution in charge of dictating the policy of science and technology in the country, currently has, among others, two recognitions, one to nationally recognized researchers which he calls "national system of researchers", which grants the distinction through an economic recognition to the teacher-researchers, 
mainly for their productivity of indexed international articles; the other recognition is the one that grants to the programs that have a teaching staff of SNI'S, called "national program of postgraduate of quality" among the requirements to be part of this distinction are the academic productivity of teacher-student, enrollment, terminal efficiency etc., so both teachers and universities seek to obtain such recognition and are working to achieve their income, to meet the requirements.

\section{Conclusions}

Interdiscipline in the environmental sector of Mexico is in the process of development. As we have observed throughout the work, the demand for interdisciplinary professionals has been and is growing. The academy within its formative role, depending on a government, has made its efforts which have fallen far short of what is required, somewhat as we analyze for issues unrelated to them (political context, budget etc.) and other internal (the rigidity of teachers facing change). The international context has marked the tendencies of the type of personnel required for the new challenges demanded by institutions to face current situations. However, Mexico continues with educational policies and the science and technology distant itself from promoting the formation of resources and interdisciplinary projects, With these measures the academy participates somewhat distant and perhaps challenges to move from the discipline to the Interdiscipline and a more to the Transdiscipline, by the repercussions that this can bring as to face the policies of the system. The environmental sector will continue to advance in Mexico with or without interdisciplinary personnel, as it has been doing, the truth is that we will continue to lose resources day by day as in the beginning of the history of the country, independent on paper and dependent in practice.

Author Contributions: Paper was written collaboratively by the authors.

Funding: This research received no external funding.

Conflicts of Interest: The authors declare no conflict of interest.

\section{References}

[1] Martínez-Rodríguez, M. C. (2010). Bicentenario de México en Políticas Ambientales: Primera Parte. Calidad Ambiental, 27 (1), pp. 21-24.

[2] Martínez-Rodríguez, M. C. (2010). Bicentenario de México en Políticas Ambientales: Segunda Parte. Calidad Ambiental, 27 (2), pp. 21-23.

[3] González, R. J. (2004). Oferta y demanda educativas en Nueva España (s. XVII). Las salidas profesionales de los graduados superiores de la Universidad de México. Revista Complutense de Historia de América, 30, pp. 41-51

[4] Martínez-Rodríguez, M. C. (2010). Bicentenario de México en Políticas Ambientales: Tercera Parte. Calidad Ambienta, 27 (3), pp. 18-23.

[5] Marsiske, R. (2006). La universidad de México: Historia y Desarrollo. Revista Historia de la Educación Latinoamericana, 8, pp. 11-34.

[6] Consejo Superior de Salubridad. (1896). Boletín del Consejo Superior de Salubridad, 2 (4).

[7] Martínez-Rodríguez, M. C. (2010). Bicentenario de México en Políticas Ambientales: Cuarta Parte, Calidad Ambiental, 27 (4), pp. 21-25.

[8] Lezama, J. \& Graizbord, B. (Eds.). (2010). Los grandes problemas de México. IV - Medio ambiente. Mexico City, Mexico: El Colegio de México.

[9] Martínez-Rodríguez, M. C. (2010). Bicentenario de México en Políticas Ambientales: Quinta Parte. Calidad Ambiental, 27 (5), pp. 19-25.

[10] Pérez-Calderón, J. (2010). La política ambiental en México: Gestión e instrumentos económicos. El Cotidiano, (162), pp. 91-97.

[11] Martínez-Rodríguez, M. C. (2010). Bicentenario de México en Políticas Ambientales: Sexta Parte, Calidad Ambiental, 27 (6), pp. 21-25.

[12] López-Zárate, R., González-Cuevas O. \& CasillasAlvarado M. A. (2000). Una historia de la UAM. Sus primeros 25 años. Mexico City, Mexico: Universidad Autónoma Metropolitana.

[13] Martínez-Rodríguez, M. C., Andrade-Vallejo, A. \& Ángeles-Castro G. (2015) La interdisciplinariedad en el trabajo en redes inEstudios sobre el desarrollo regional en México desde la perspectiva financiera, social, educativa y empresarial. Un enfoque interdisciplinario. Mexico City, Mexico: Colofón Editores.

[14] Instituto Politécnico Nacional. (2017). http://www.ipn.mx (accesed October 20, 2017)

[15] Centro Regional de Investigaciones Multidisciplinarias CRIM. (2017). http://www.crim.unam.mx/web/ (accesed October 12, 2017) 
[16] Secretaría de Gestión Estratégica. Dirección de planeación del Instituto Politécnico Nacional. (2011). í Manual de organizacin del Centro Interdisciplinario de Investigaciones y Estudios sobre Medio Ambiente y Desarrollo.

[17] Centro Interdisciplinario de Investigaciones y Estudios sobre Medio Ambiente y Desarrollo CIIEMAD. (2017). http://www.ciiemad.ipn.mx (accesed October 30, 2017)

\section{About the Authors}

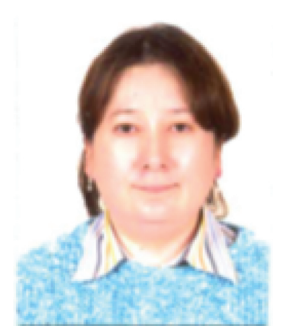

María Concepción Martínez Rodríguez is a Professor of Governance in the Interdisciplinary Center of Research and Studies on Environment and Development (CIIEMAD) of the National Polytechnic Institute (Instituto Politécnico Nacional-IPN) in Mexico City. Concepción's research focuses mainly on environmental public policy for Mexico and Latin America. She has written 5 books and 16 chapters for books on the topic. She has done research stay in the Twente University in the Netherlands and in Harvard University. Concepción received both her doctorate and master's degree in Public Policy and Management from the Monterrey Institute of Technology and Higher Educaction (ITESM) and her bachelor degree in Chemical Engineering from IPN.

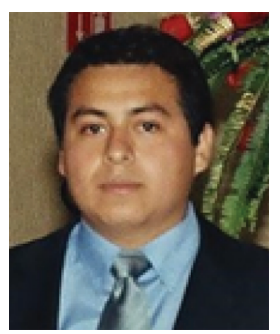

Luis Ángel Jiménez López is a Geological Engineer graduated from the National Polytechnic Institute of Mexico, has 7 years of experience in the mining industry in the exploration area, working with deposits in sedimentary, igneous and metamorphic rocks. He is currently a Master of Science student in Environmental Studies and Sustainability at CIIEMAD- IPN, focusing on environmental geology and risk areas. Member of the Society of Economic Geology.

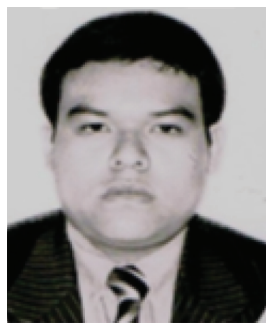

Omar Mayorga Pérez is a research assistant in the Interdisciplinary Center of Research and Studies on Environment and Development (CIIEMAD) of the National Polytechnic Institute (IPN) in Mexico City. His research is centered mainly in Technology for Sustainable Development. Omar received his bachelor degree in Biotechnological Engineering from IPN. He is currently doing a research stay at CIIEMAD. 
Table 1: Environmental Law (Source: [17])

\begin{tabular}{|c|c|c|}
\hline Biosciences and Engineering & $\begin{array}{l}\text { Territory and } \\
\text { Environment }\end{array}$ & $\begin{array}{l}\text { Society and } \\
\text { Environmental } \\
\text { Policy }\end{array}$ \\
\hline Health and Environment & $\begin{array}{l}\text { Integrated management of bi- } \\
\text { otic resources and Conserva- } \\
\text { tion Biology }\end{array}$ & Environmental Law \\
\hline $\begin{array}{l}\text { Study of the mechanisms of action } \\
\text { of the hypoglycemic effect of medici- } \\
\text { nal plants used in the treatment of } \\
\text { diabetes }\end{array}$ & $\begin{array}{l}\text { Social Anthropology, Fisher- } \\
\text { men and Riparian Fishing }\end{array}$ & $\begin{array}{l}\text { Environmental Manage- } \\
\text { ment }\end{array}$ \\
\hline $\begin{array}{l}\text { The protein crown as a modulator of } \\
\text { the inflammatory response to nano- } \\
\text { materials }\end{array}$ & $\begin{array}{l}\text { Fishing Policies in Mexico and } \\
\text { Latin America }\end{array}$ & Fisheries legislation \\
\hline $\begin{array}{l}\text { Evaluation of the adverse effects in- } \\
\text { duced by nanomaterials }\end{array}$ & $\begin{array}{l}\text { Coastal Development and En- } \\
\text { vironment }\end{array}$ & $\begin{array}{l}\text { Public Policies and the } \\
\text { Environment }\end{array}$ \\
\hline $\begin{array}{l}\text { Synthesis of Nanostructures, Appli- } \\
\text { cations and Environmental Implica- } \\
\text { tions }\end{array}$ & $\begin{array}{l}\text { Territorial Transformations } \\
\text { and "Arrangement" of the } \\
\text { Territory }\end{array}$ & $\begin{array}{l}\text { Socio-urban processes } \\
\text { and the environment }\end{array}$ \\
\hline $\begin{array}{l}\text { Simulation of Environmental Capil- } \\
\text { lary Processes }\end{array}$ & $\begin{array}{l}\text { Development and Sociour- } \\
\text { bano Metropolitan Environ- } \\
\text { ment and Historical Centers }\end{array}$ & $\begin{array}{l}\text { Territory, tourism and } \\
\text { environment }\end{array}$ \\
\hline $\begin{array}{l}\text { Nanoproducts, Nano-waste and Ur- } \\
\text { ban Solid Waste }\end{array}$ & Regional Socio-Urban Studies & $\begin{array}{l}\text { Metropolitan urban de- } \\
\text { velopment }\end{array}$ \\
\hline $\begin{array}{l}\text { Pollution and atmospheric monitor- } \\
\text { ing }\end{array}$ & $\begin{array}{l}\text { Development, Environment and Sus- } \\
\text { tainability }\end{array}$ & Research Methodology \\
\hline Environmental Toxicology & $\begin{array}{l}\text { The complexity in sustainable } \\
\text { issues of socio-environmental } \\
\text { problems }\end{array}$ & $\begin{array}{l}\text { Environmental Educa- } \\
\text { tion }\end{array}$ \\
\hline $\begin{array}{l}\text { Pollutant Evaluation in Environmen- } \\
\text { tal samples }\end{array}$ & $\begin{array}{l}\text { Territory, city, capital and } \\
\text { spaces in transformation }\end{array}$ & Educational Innovation \\
\hline $\begin{array}{l}\text { Ecophysiology and Bioenergetics of } \\
\text { key species in freshwater systems }\end{array}$ & $\begin{array}{l}\text { Territorial and Environmental } \\
\text { Transformations }\end{array}$ & Sustainable Universities \\
\hline $\begin{array}{l}\text { Water quality, geochemistry, accu- } \\
\text { mulation of toxic metals in water, } \\
\text { sediments in soil and fish (rivers, es- } \\
\text { tuaries and coasts) }\end{array}$ & Alternative Turism & Governance \\
\hline $\begin{array}{l}\text { Identification of Tsunami deposits } \\
\text { (Present and paleo deposits) }\end{array}$ & $\begin{array}{l}\text { Urban Transportation, Envi- } \\
\text { ronmental Audit }\end{array}$ & Public Policy \\
\hline $\begin{array}{l}\text { Degradation and restoration of Man- } \\
\text { groves }\end{array}$ & $\begin{array}{l}\text { Planning and Public Policy } \\
\text { (environmental, rural and fis- } \\
\text { cal) }\end{array}$ & $\begin{array}{l}\text { Public and environmen- } \\
\text { tal management }\end{array}$ \\
\hline Paleoclimatology studies & $\begin{array}{l}\text { Environmental and Ecological } \\
\text { Economics (valuation and in- } \\
\text { dicators) }\end{array}$ & $\begin{array}{l}\text { Strategic environmental } \\
\text { planning in Mexico }\end{array}$ \\
\hline
\end{tabular}


Table 1: Environmental Law (continued)

\begin{tabular}{|c|c|c|}
\hline Biosciences and Engineering & $\begin{array}{l}\text { Territory and } \\
\text { Environment }\end{array}$ & $\begin{array}{l}\text { Society and } \\
\text { Environmental } \\
\text { Policy }\end{array}$ \\
\hline Biological Treatment of Wastewater & $\begin{array}{l}\text { Sustainable Use of Natural Re- } \\
\text { sources in agrarian centers }\end{array}$ & $\begin{array}{l}\text { Territorial ecological or- } \\
\text { dering }\end{array}$ \\
\hline $\begin{array}{l}\text { Geo-environmental Studies and Geo- } \\
\text { statistics }\end{array}$ & $\begin{array}{l}\text { Food Security and Local De- } \\
\text { velopment }\end{array}$ & $\begin{array}{l}\text { Integral Coastal Man- } \\
\text { agement }\end{array}$ \\
\hline Applied Environmental Geomatics & Hydrometeorological risks & $\begin{array}{l}\text { Coastal - Marina Pollu- } \\
\text { tion }\end{array}$ \\
\hline $\begin{array}{l}\text { Synthesis, characterization and eval- } \\
\text { uation of catalysts for obtaining low } \\
\text { sulfur fuels }\end{array}$ & $\begin{array}{l}\text { Geological characterization of } \\
\text { areas susceptible to landslides }\end{array}$ & Public Policy \\
\hline $\begin{array}{l}\text { Biosciences Limnology Characteriza- } \\
\text { tion of inland waters }\end{array}$ & $\begin{array}{l}\text { Identification of landslide de- } \\
\text { posits }\end{array}$ & $\begin{array}{l}\text { Housing Policy and En- } \\
\text { vironment }\end{array}$ \\
\hline $\begin{array}{l}\text { Pollution and environmental deteri- } \\
\text { oration by metals, bioavailability in } \\
\text { Aquatic Systems Geochemical cycles }\end{array}$ & $\begin{array}{l}\text { Natural Resources (soil, water, } \\
\text { minerals) }\end{array}$ & $\begin{array}{l}\text { Territorial Transforma- } \\
\text { tions }\end{array}$ \\
\hline $\begin{array}{l}\text { Environmental analysis in the sedi- } \\
\text { ment water interface and the animal } \\
\text { soil plant relationship }\end{array}$ & Regional Urban Development & $\begin{array}{l}\text { Housing, Environment } \\
\text { and Quality of Life }\end{array}$ \\
\hline Hydrometeorological phenomena & Sustainable Architecture & Territorial Planning \\
\hline Impact of Marine Resources & $\begin{array}{l}\text { Analysis of normative bodies } \\
\text { from their implications in soci- } \\
\text { ety, the environment, climate } \\
\text { change, and sustainable devel- } \\
\text { opment }\end{array}$ & $\begin{array}{l}\text { Management of natural } \\
\text { resources and Sustain- } \\
\text { able Rural Development }\end{array}$ \\
\hline Impact of Climate Change in Mexico & Environmental Regulation & Agroecology \\
\hline $\begin{array}{l}\text { Pollution and monitoring of contam- } \\
\text { inated sites }\end{array}$ & Territorial Reservations & $\begin{array}{l}\text { Rural Development Poli- } \\
\text { cies }\end{array}$ \\
\hline $\begin{array}{l}\text { Prevention and Control of Pollution } \\
\text { (Solid Waste, Soil Remediation) }\end{array}$ & Environmental diagnosis & $\begin{array}{l}\text { Rural History and Cul- } \\
\text { ture }\end{array}$ \\
\hline $\begin{array}{l}\text { Residual and synthetic natural fibers } \\
\text { for the automated conformation of } \\
\text { eco-friendly technical textiles with } \\
\text { the environment for their application } \\
\text { in ballistics and civil engineering }\end{array}$ & Environmental Evolution & $\begin{array}{l}\text { Participatory method- } \\
\text { ologies }\end{array}$ \\
\hline $\begin{array}{l}\text { Econcomposites generated by uncon- } \\
\text { ventional processes and the dynam- } \\
\text { ics associated with these processes }\end{array}$ & Restoration of degraded soils & $\begin{array}{l}\text { Public Policy and Envi- } \\
\text { ronment }\end{array}$ \\
\hline $\begin{array}{l}\text { Controlled functionalization of fi- } \\
\text { brous materials and regulated poros- } \\
\text { ity with applications mainly agribusi- } \\
\text { ness, ballistics, electronics, civil en- } \\
\text { gineering and in the production of } \\
\text { low environmental impact fuels }\end{array}$ & $\begin{array}{l}\text { Environmental Impact in De- } \\
\text { velopment Works }\end{array}$ & Science Methodology \\
\hline
\end{tabular}


Table 2: Projects Developed in CIIEMAD (source: [17])

\begin{tabular}{|c|c|c|}
\hline Biosciences and Engineering & $\begin{array}{l}\text { Territory and } \\
\text { Environment }\end{array}$ & $\begin{array}{c}\text { Society and } \\
\text { Environmental } \\
\text { Policy }\end{array}$ \\
\hline $\begin{array}{l}\text { Heavy metals in the muscular and } \\
\text { liver tissue of sharks of Baja Califor- } \\
\text { nia Sur }\end{array}$ & $\begin{array}{l}\text { Study of the dynamics of use } \\
\text { and appropriation of resources } \\
\text { in Chiloé Island, Chile }\end{array}$ & $\begin{array}{l}\text { Study on successful Pub- } \\
\text { lic Policies in the world } \\
\text { of sustainable develop- } \\
\text { ment }\end{array}$ \\
\hline $\begin{array}{l}\text { Bioaccumulation of heavy metals } \\
\text { (mercury and cadmium) and sele- } \\
\text { nium in the stingrays of the western } \\
\text { coast of Baja California Sur }\end{array}$ & $\begin{array}{l}\text { Biological-fishing study } \\
\text { shrimp species of coastal } \\
\text { lagoon systems of Yucatan }\end{array}$ & $\begin{array}{l}\text { Social participation to } \\
\text { solve environmental } \\
\text { problems: governance } \\
\text { and climate change }\end{array}$ \\
\hline $\begin{array}{l}\text { Study of the mechanisms of action of } \\
\text { the hypoglycemic effect of the total } \\
\text { extract and subfractions of Ibervillea } \\
\text { sonorae in a hyperglycemic rat model }\end{array}$ & $\begin{array}{l}\text { Transformations and uses of } \\
\text { space in the coast of Colima }\end{array}$ & $\begin{array}{l}\text { Environmental Prospec- } \\
\text { tive, a contribution for } \\
\text { the territorial ecological } \\
\text { ordering of the Munici- } \\
\text { pality of Tlaxco, Tlax- } \\
\text { cala }\end{array}$ \\
\hline $\begin{array}{l}\text { Activation of the CFTR channel as } \\
\text { a possible mechanism of action in } \\
\text { Chronic Kidney Disease associated } \\
\text { with fluoride exposure }\end{array}$ & $\begin{array}{l}\text { Socio-urban environmental } \\
\text { challenges in México City; } \\
\text { case Delegation Cuauhtémoc }\end{array}$ & $\begin{array}{l}\text { Plan of Action for the } \\
\text { sustainable development } \\
\text { of CIIEMAD }\end{array}$ \\
\hline $\begin{array}{l}\text { Synthesis of semiconductor nanos- } \\
\text { tructures and the inventory of their } \\
\text { nano-waste involved }\end{array}$ & $\begin{array}{l}\text { Impact of the informal sector } \\
\text { of the economy on the architec- } \\
\text { tural urban cultural heritage } \\
\text { of the Historic Center of Mex- } \\
\text { ico City }\end{array}$ & $\begin{array}{l}\text { Diagnosis of institu- } \\
\text { tional capacities for the } \\
\text { environmental manage- } \\
\text { ment of the states in } \\
\text { Mexico }\end{array}$ \\
\hline $\begin{array}{l}\text { Analysis of nano-waste generated } \\
\text { during the obtaining of oxide- } \\
\text { metallic nanostructures }\end{array}$ & $\begin{array}{l}\text { The socio-environmental prob- } \\
\text { lems and the territory in Mex- } \\
\text { ico }\end{array}$ & $\begin{array}{l}\text { Baseline diagnosis of ur- } \\
\text { ban solid waste manage- } \\
\text { ment for the formula- } \\
\text { tion of an integral man- } \\
\text { agement plan for urban } \\
\text { waste in the state of } \\
\text { Quintana Roo, Mexico }\end{array}$ \\
\hline $\begin{array}{l}\text { Sustainability of the productive pro- } \\
\text { cesses in the synthesis of Nanostruc- } \\
\text { tured Materials }\end{array}$ & $\begin{array}{l}\text { The socio-urban environmen- } \\
\text { tal spaces and the territorial } \\
\text { organization in the sustainabil- } \\
\text { ity? }\end{array}$ & $\begin{array}{l}\text { Design of methodologi- } \\
\text { cal instruments and cre- } \\
\text { ation of a data bank for } \\
\text { the construction of the } \\
\text { environmental history of } \\
\text { the ejido San José de } \\
\text { las palmas, municipality. } \\
\text { Union of San Antonio, } \\
\text { Jalisco }\end{array}$ \\
\hline
\end{tabular}


Table 2: Projects Developed in CIIEMAD (continued)

\begin{tabular}{|c|c|c|}
\hline Biosciences and Engineering & $\begin{array}{l}\text { Territory and } \\
\text { Environment }\end{array}$ & $\begin{array}{c}\text { Society and } \\
\text { Environmental } \\
\text { Policy }\end{array}$ \\
\hline $\begin{array}{l}\text { Mitigation strategies for greenhouse } \\
\text { gases generated by urban solid waste } \\
\text { in Mexico }\end{array}$ & $\begin{array}{l}\text { Definition of an environmental } \\
\text { frame of reference and diagno- } \\
\text { sis of compliance in the terri- } \\
\text { torial organization of mobility } \\
\text { and urban transport for a del- } \\
\text { egation of the federal district }\end{array}$ & $\begin{array}{l}\text { Socio-environmental } \\
\text { modifications in rural } \\
\text { communities in the } \\
\text { city of Mexico. Case } \\
\text { study: Ocuilan, State of } \\
\text { Mexico }\end{array}$ \\
\hline $\begin{array}{l}\text { Towards green Nano science: natu- } \\
\text { ral resources, production processes, } \\
\text { nanomaterial, nanoproducts and } \\
\text { nanorresidues }\end{array}$ & $\begin{array}{l}\text { Criteria for articulation of pub- } \\
\text { lic transport modes }\end{array}$ & $\begin{array}{l}\text { Diagnosis of affectations } \\
\text { to the hydric resource } \\
\text { caused by the open-air } \\
\text { dump in Zinápecuaro, } \\
\text { Mich. }\end{array}$ \\
\hline $\begin{array}{l}\text { Neurotoxic effect of lead in the } \\
\text { central nervous system. } \\
\text { the metabolism of dopamine and } \\
\text { tetrahydrobiopterin }\end{array}$ & $\begin{array}{l}\text { Perspectives of urban environ- } \\
\text { mental policies for the sustain- } \\
\text { ability of the city: Mexico City }\end{array}$ & \\
\hline $\begin{array}{l}\text { Urban atmospheric particles. } \\
\text { Sources, composition and toxicity }\end{array}$ & $\begin{array}{l}\text { Design of strategic socio- } \\
\text { environmental lines for the } \\
\text { 'state program for the preven- } \\
\text { tion of integral waste manage- } \\
\text { ment (PEPGIR) in Quintana } \\
\text { Roo, Mexico }\end{array}$ & \\
\hline $\begin{array}{l}\text { Biotechnological alternatives for the } \\
\text { processing and reuse of fruit and veg- } \\
\text { etable waste from the northern area } \\
\text { of Mexico City }\end{array}$ & $\begin{array}{l}\text { Methodological analysis of en- } \\
\text { vironmental audit practices } \\
\text { with participation of social ac- } \\
\text { tors }\end{array}$ & \\
\hline $\begin{array}{l}\text { Evaluation of the geomobility of } \\
\text { heavy metals in the surface sedi- } \\
\text { ments of the mining and metallur- } \\
\text { gical district of Santa Rosalia, Baja } \\
\text { California Sur }\end{array}$ & $\begin{array}{l}\text { Application of environmental } \\
\text { economic evaluation indicators } \\
\text { for social producers }\end{array}$ & \\
\hline $\begin{array}{l}\text { Establishment of a Management Pro- } \\
\text { gram for the coastal zone of the } \\
\text { southern region of the Gulf of Cali- } \\
\text { fornia }\end{array}$ & $\begin{array}{l}\text { Indicators of analysis of eco- } \\
\text { nomic evaluation with environ- } \\
\text { mental criteria for agrarian nu- } \\
\text { clei }\end{array}$ & \\
\hline $\begin{array}{l}\text { Isotopic enrichment and trophic lev- } \\
\text { els of the prey and habitats exploited } \\
\text { by the California sea lion off Mag- } \\
\text { dalena Bay, Mexico }\end{array}$ & $\begin{array}{l}\text { Methodology of analysis of sus- } \\
\text { tainable use of lands of com- } \\
\text { mon use in the state of Ver- } \\
\text { acruz }\end{array}$ & \\
\hline $\begin{array}{l}\text { Effect of inorganic fertilizers on the } \\
\text { degradation of triazine herbicides }\end{array}$ & $\begin{array}{l}\text { Indicators of environmental } \\
\text { degradation in the Zahuapan } \\
\text { river basin, Tlaxcala state }\end{array}$ & \\
\hline $\begin{array}{l}\text { Bioprocesses for the degradation } \\
\text { of synthetic azo-anthraquinone and } \\
\text { trizinic dyes }\end{array}$ & $\begin{array}{l}\text { Analysis of the environmental } \\
\text { policy in Mexico and its cur- } \\
\text { rent instruments enforced in } \\
2011\end{array}$ & \\
\hline
\end{tabular}


Table 2: Projects Developed in CIIEMAD (continued)

\begin{tabular}{|c|c|c|}
\hline Biosciences and Engineering & $\begin{array}{l}\text { Territory and } \\
\text { Environment }\end{array}$ & $\begin{array}{l}\text { Society and } \\
\text { Environmental } \\
\text { Policy }\end{array}$ \\
\hline $\begin{array}{l}\text { Bioprocesses to mineralize the herbi- } \\
\text { cides derived from urea, diuron and } \\
\text { linuron }\end{array}$ & $\begin{array}{l}\text { Evaluation of the Methodolo- } \\
\text { gies of Federal Public Policies: } \\
\text { Strengths and Weaknesses }\end{array}$ & \\
\hline $\begin{array}{l}\text { Presence of genes for the catabolism } \\
\text { of herbicides in microbial consor- } \\
\text { tia and their relation to the oper- } \\
\text { ational stability of biobarriers uti- } \\
\text { lizadas para su degradación }\end{array}$ & $\begin{array}{l}\text { Diagnosis of the indigenous } \\
\text { ecotourism policy in Mexico } \\
2000-2006\end{array}$ & \\
\hline $\begin{array}{l}\text { Location and analysis of critical ar- } \\
\text { eas due to the use of pesticides } \\
\text { in Mexico. Case study: Tecolutla } \\
\text { River, Tecolutla Sub-basin in Ver- } \\
\text { acruz }\end{array}$ & $\begin{array}{l}\text { Health diagnosis of the Villa } \\
\text { Montemorelos and El Arenal } \\
\text { communities of Durango, Mex- } \\
\text { ico }\end{array}$ & \\
\hline $\begin{array}{l}\text { Development of a bio-enrichment } \\
\text { process of a biobarrera for degra- } \\
\text { dation of the commercial herbicide } \\
\text { Tordón }(2,4-\mathrm{D}+\text { Picloram })\end{array}$ & $\begin{array}{l}\text { Development of a GIS of sites } \\
\text { contaminated by agrochemi- } \\
\text { cals in the municipalities of } \\
\text { Tecolutla, Gutiérrez Zamora } \\
\text { and Papantla in Veracruz, } \\
\text { Mexico }\end{array}$ & \\
\hline $\begin{array}{l}\text { Location and analysis of critical ar- } \\
\text { eas for the use of pesticides in Mexico } \\
\text { (Municipalities of Gutiérrez Zamora } \\
\text { and Papantla in Veracruz) }\end{array}$ & $\begin{array}{l}\text { Health effects of the human } \\
\text { populations of the San Pedro } \\
\text { Mezquital Basin as a result of } \\
\text { the management of its wastew- } \\
\text { ater }\end{array}$ & \\
\hline $\begin{array}{l}\text { Isolation of microorganisms with the } \\
\text { ability to degrade formulations of } \\
\text { herbicides containing nicosulfuron }\end{array}$ & $\begin{array}{l}\text { Environmental risk factors of } \\
\text { sanitary landfills in the Fed- } \\
\text { eral District and the conur- } \\
\text { bated area and their relation } \\
\text { to health, quality of life and } \\
\text { precarious work of segregators }\end{array}$ & \\
\hline $\begin{array}{l}\text { Hydro geochemical Rector Study of } \\
\text { the Wells in the Aquifers of the } \\
\text { Metropolitan Zone, Puebla (First } \\
\text { Stage) }\end{array}$ & $\begin{array}{l}\text { Strategic planning of the } \\
\text { productive chains of smaller } \\
\text { pelagic fish and clam Catarina, } \\
\text { for its sustainable use }\end{array}$ & \\
\hline $\begin{array}{l}\text { Network of Monitoring Stations for } \\
\text { the Preservation, Conservation and } \\
\text { Improvement of Water Quality in the } \\
\text { Alto Atoyac Basin Corresponding to } \\
\text { the State of Puebla }\end{array}$ & $\begin{array}{l}\text { Characterization of the geolog- } \\
\text { ical hazards present in Motoz- } \\
\text { intla, Chiapas }\end{array}$ & \\
\hline \multicolumn{3}{|l|}{$\begin{array}{l}\text { Update of the } 2016 \text { Tariff Agreement, } \\
\text { Water of Puebla }\end{array}$} \\
\hline $\begin{array}{l}\text { Responsible Management of Wet- } \\
\text { lands and Micro-basins and in turn } \\
\text { Maintaining Ecological Balance in } \\
\text { the City of Puebla }\end{array}$ & & \\
\hline $\begin{array}{l}\text { Biofilter Demonstration Project at } \\
\text { the Valsequillo Dam }\end{array}$ & & \\
\hline
\end{tabular}


Table 2: Projects Developed in CIIEMAD (continued)

\section{Biosciences and Engineering}

Territory and

Environment
Society and

Environmental

Policy

\footnotetext{
Evaluation of the toxicity of metals and concentration patterns of Habitat (Water and Sediment) and prey of the Sea Lion of Magdalena Bay, Baja California

Statistical analysis of extreme hydrometeorological events in the south and southeast of Mexico

Analysis and dissemination of the legislation applicable to fishing activity in the state of Quintana Roo Climate change and the occurrence of extreme weather events in Mexico during the 20th century

Scenarios and Vulnerability to Climate Change of Fishing Activity in the Gulf of California
} 
Table 3: Elective Courses in CIIEMAD (source: [17])

\begin{tabular}{|c|c|c|}
\hline Biosciences and Engineering & $\begin{array}{l}\text { Territory and } \\
\text { Environment }\end{array}$ & $\begin{array}{c}\text { Society and } \\
\text { Environmental } \\
\text { Policy }\end{array}$ \\
\hline Biofuels and Environment & $\begin{array}{l}\text { History of the Environment } \\
\text { and Development in Mexico } \\
(1950-2000)\end{array}$ & $\begin{array}{l}\text { Patents in Environment } \\
\text { and Development }\end{array}$ \\
\hline $\begin{array}{l}\text { Integrated Management of Urban } \\
\text { Solid Waste }\end{array}$ & $\begin{array}{l}\text { Ecological Planning of the Ter- } \\
\text { ritory }\end{array}$ & $\begin{array}{l}\text { Preparation and Presen- } \\
\text { tation of Research Prod- } \\
\text { ucts }\end{array}$ \\
\hline Environmental Toxicology & $\begin{array}{l}\text { Territory, Environment and } \\
\text { Sustainable Development }\end{array}$ & Statistics \\
\hline $\begin{array}{l}\text { Comprehensive management of haz- } \\
\text { ardous waste }\end{array}$ & $\begin{array}{l}\text { Environmental } \\
\text { impact assessment }\end{array}$ & $\begin{array}{l}\text { Introduction to Quali- } \\
\text { tative Methods of Re- } \\
\text { search Applied to Envi- } \\
\text { ronmental Analysis }\end{array}$ \\
\hline $\begin{array}{l}\text { Clinical principles of exposure to en- } \\
\text { vironmental toxins }\end{array}$ & $\begin{array}{l}\text { Environmental and Ecological } \\
\text { Economics }\end{array}$ & $\begin{array}{l}\text { Fundamentals of Geo- } \\
\text { graphic Information Sys- } \\
\text { tems for Environmental } \\
\text { Studies }\end{array}$ \\
\hline $\begin{array}{l}\text { Introduction to Environmental } \\
\text { Chemistry }\end{array}$ & $\begin{array}{l}\text { Methodological Tools for Evalua- } \\
\text { tion of Programs and Public Poli- } \\
\text { cies }\end{array}$ & $\begin{array}{l}\text { The Art of Scientific } \\
\text { Writing }\end{array}$ \\
\hline $\begin{array}{l}\text { Selected topics of environmental epi- } \\
\text { demiology }\end{array}$ & $\begin{array}{l}\text { Introduction to Public Policies } \\
\text { and their Evaluation }\end{array}$ & Advanced Statistics \\
\hline \multirow[t]{2}{*}{ Risks due to natural phenomena } & Governance & \\
\hline & $\begin{array}{l}\text { Transdisciplinary research for } \\
\text { sustainability }\end{array}$ & \\
\hline \multirow[t]{7}{*}{ Geo-environmental methods } & Environmental Education & \\
\hline & $\begin{array}{l}\text { The paradigm of integral ecol- } \\
\text { ogy as a path for landscape } \\
\text { management }\end{array}$ & \\
\hline & Environmental Law & \\
\hline & $\begin{array}{l}\text { Socio-environmental political } \\
\text { economy }\end{array}$ & \\
\hline & $\begin{array}{l}\text { Environmental policy and its } \\
\text { instruments }\end{array}$ & \\
\hline & $\begin{array}{l}\text { Strategic Environmental Plan- } \\
\text { ning in Mexico }\end{array}$ & \\
\hline & $\begin{array}{l}\text { Organizations and Sustainable } \\
\text { Institutions }\end{array}$ & \\
\hline
\end{tabular}


Table 4: Master's Thesis in Science in Environmental Studies and Sustainability Studies (source: [17])

\begin{tabular}{|c|c|c|}
\hline Biosciences and Engineering & $\begin{array}{l}\text { Territory and } \\
\text { Environment }\end{array}$ & $\begin{array}{c}\text { Society and } \\
\text { Environmental } \\
\text { Policy. }\end{array}$ \\
\hline $\begin{array}{l}\text { Evaluation of tropospheric aerosols } \\
\text { of the AMCM by means of GOES } \\
\text { satellite images. }\end{array}$ & $\begin{array}{l}\text { Analysis of the Localized Agro- } \\
\text { Food System of Coffee in } \\
\text { the Municipality of Naupan, } \\
\text { Puebla. }\end{array}$ & $\begin{array}{l}\text { The environmental } \\
\text { knowledge of the visitor } \\
\text { of the protected natural } \\
\text { areas: Case study Na- } \\
\text { tional Park "Cumbres } \\
\text { del Ajusco". }\end{array}$ \\
\hline $\begin{array}{l}\text { Electrochemical treatment of } \\
\text { wastewater derived from the } \\
\text { leaching of natural rubber latex } \\
\text { products. }\end{array}$ & $\begin{array}{l}\text { Social vulnerability and adap- } \\
\text { tation of the Apatlaco River } \\
\text { basin to the effects of climate } \\
\text { change on water availability. }\end{array}$ & $\begin{array}{l}\text { From citizen participa- } \\
\text { tion in Environmental } \\
\text { Policies to sustainabil- } \\
\text { ity. A process under con- } \\
\text { struction. }\end{array}$ \\
\hline $\begin{array}{l}\text { Waste management plans for high- } \\
\text { volume generators: The case of the } \\
\text { Abastos plant in Mexico City. }\end{array}$ & $\begin{array}{l}\text { Impact of architectural reuse } \\
\text { in the socio-urban environ- } \\
\text { ment. Case study: Two sets of } \\
\text { homes located in the historic } \\
\text { center of Mexico City. }\end{array}$ & $\begin{array}{l}\text { Guidelines for ecological } \\
\text { ordering in archaeolog- } \\
\text { ical zones: Case study } \\
\text { Cuicuilco, Mexico. }\end{array}$ \\
\hline $\begin{array}{l}\text { Pharmacological evaluation of the } \\
\text { hypoglycaemic effect of "Ibervillea } \\
\text { sonorae" }\end{array}$ & $\begin{array}{l}\text { Community Cultural Tourism } \\
\text { in the safeguard of the chinam- } \\
\text { pero heritage in San Gregorio } \\
\text { Atlapulco, Xochimilco, DF. }\end{array}$ & $\begin{array}{l}\text { Towards cross-effects in } \\
\text { poverty and environ- } \\
\text { ment? Analysis of pub- } \\
\text { lic policies. The case of } \\
\text { Lacanja, Chiapas. }\end{array}$ \\
\hline $\begin{array}{l}\text { Optimization of the composting pro- } \\
\text { cess produced from the organic frac- } \\
\text { tion of urban solid waste generated } \\
\text { in Mexico City. }\end{array}$ & $\begin{array}{l}\text { Comparative study between } \\
\text { conventional apiculture pro- } \\
\text { duction and fair trade or- } \\
\text { ganic beekeeping production } \\
\text { by small producers of the State } \\
\text { of Mexico. }\end{array}$ & $\begin{array}{l}\text { Analysis of intergovern- } \\
\text { mental cooperation in } \\
\text { the management of the } \\
\text { water resources of Lake } \\
\text { Tlahuac-Xico. An ap- } \\
\text { proach from the public } \\
\text { policy approach. }\end{array}$ \\
\hline $\begin{array}{l}\text { Development of computational tools } \\
\text { for the management of environmen- } \\
\text { tal databases: Case study of urban } \\
\text { agricultural ecosystems in Mexico } \\
\text { City. }\end{array}$ & $\begin{array}{l}\text { Use of remote sensing systems } \\
\text { and geographic information in } \\
\text { the participatory diagnosis of } \\
\text { the rural coffee territory of } \\
\text { the municipality of Xicotepec, } \\
\text { Puebla. }\end{array}$ & $\begin{array}{l}\text { Conflicts, denomination } \\
\text { of Magical Town and the } \\
\text { paper amate in Pahuat- } \\
\text { lan de Valle, Puebla. }\end{array}$ \\
\hline $\begin{array}{l}\text { Estimation of methane emissions } \\
\text { from the Bordo Poniente Landfill } \\
\text { through satellite images. }\end{array}$ & & $\begin{array}{l}\text { Diagnosis of the physical } \\
\text { dimension of the Tech- } \\
\text { nological University of } \\
\text { Tula Tepeji as a basis for } \\
\text { an environmental educa- } \\
\text { tion program. }\end{array}$ \\
\hline
\end{tabular}


Table 4: Master's Thesis in Science in Environmental Studies and Sustainability Studies (continued)

\begin{tabular}{|c|c|c|}
\hline Biosciences and Engineering & $\begin{array}{l}\text { Territory and } \\
\text { Environment }\end{array}$ & $\begin{array}{c}\text { Society and Environmental } \\
\text { Policy. }\end{array}$ \\
\hline $\begin{array}{l}\text { Study of the valuation of organic } \\
\text { waste contained in the urban solid } \\
\text { waste generated in the Federal Dis- } \\
\text { trict. }\end{array}$ & & $\begin{array}{l}\text { Social perception of the environment } \\
\text { and urban growth in San Cristóbal } \\
\text { de las Casas Chiapas. Study among } \\
\text { young University students. }\end{array}$ \\
\hline $\begin{array}{l}\text { Program of prevention and integral } \\
\text { management of urban solid waste } \\
\text { for the municipality of Almoloya de } \\
\text { Juárez State of Mexico. }\end{array}$ & & $\begin{array}{l}\text { The theory of planned behavior and } \\
\text { the dimensions of the green school in } \\
\text { basic education. Case study: Juan } \\
\text { Ramón Jiménez Elementary School } \\
\text { and the Luis Donaldo Colosio Peda- } \\
\text { gogical Center. }\end{array}$ \\
\hline $\begin{array}{l}\text { Calculation program to estimate the } \\
\text { amount of leachates generated in san- } \\
\text { itary landfills. }\end{array}$ & & $\begin{array}{l}\text { Proposal of a public policy instru- } \\
\text { ment to regulate the sustainable pro- } \\
\text { duction and consumption of green } \\
\text { products: Eco-labeling in Mexico. }\end{array}$ \\
\hline $\begin{array}{l}\text { Evaluation of metals and non-metals } \\
\text { in the fine fraction of atmospheric } \\
\text { particles in the Metropolitan Area } \\
\text { of the Toluca Valley. }\end{array}$ & & $\begin{array}{l}\text { Elements for a non-formal education } \\
\text { program based on Human needs. }\end{array}$ \\
\hline $\begin{array}{l}\text { Experimental technical design of } \\
\text { composites from the recycling of } \\
\mathrm{PET} / \mathrm{EN} \text { and its possible appli- } \\
\text { cation in construction. }\end{array}$ & & $\begin{array}{l}\text { Proposal of energy indicators of sus- } \\
\text { tainable development for renewable } \\
\text { sources in Mexico. }\end{array}$ \\
\hline $\begin{array}{l}\text { Evaluation of the wheat straw } \\
\text { residue of the Pleurotus djamor cul- } \\
\text { ture as a substrate for anaerobic di- } \\
\text { gestion. }\end{array}$ & & $\begin{array}{l}\text { Public-Private Partnerships as a } \\
\text { public policy strategy for sustainable } \\
\text { development. Case study: The bicy- } \\
\text { cle as an alternative transport for the } \\
\text { Adolfo López Mateos and Ticoman } \\
\text { units of the IPN, Mexico City. }\end{array}$ \\
\hline $\begin{array}{l}\text { Study of the Development of the } \\
\text { Species Ricinus communis, culti- } \\
\text { vated in mining waste under green- } \\
\text { house conditions. }\end{array}$ & & $\begin{array}{l}\text { Analysis of the socio-environmental } \\
\text { impact by the denomination Mag- } \\
\text { ical Towns in Pahuatlan del Valle, } \\
\text { Puebla. }\end{array}$ \\
\hline $\begin{array}{l}\text { Valorization of natural products in } \\
\text { Teotitlán del Valle Oaxaca, with sus- } \\
\text { tainable processes. Case Lana. }\end{array}$ & & $\begin{array}{l}\text { Evaluation of the Design of the Mu- } \\
\text { nicipal Climate Action Plan (PAC- } \\
\text { MUN) as an initiative for the devel- } \\
\text { opment of a public policy. }\end{array}$ \\
\hline
\end{tabular}


Table 4: Master's Thesis in Science in Environmental Studies and Sustainability Studies (continued)

\begin{tabular}{|c|c|c|}
\hline Biosciences and Engineering & $\begin{array}{l}\text { Territory and } \\
\text { Environment }\end{array}$ & $\begin{array}{c}\text { Society and Environmental } \\
\text { Policy. }\end{array}$ \\
\hline $\begin{array}{l}\text { Mitigation actions of greenhouse } \\
\text { gases from the management of urban } \\
\text { solid waste in urban centers of more } \\
\text { than } 50 \text { thousand inhabitants. Case } \\
\text { study: Acapulco de Juárez, Guer- } \\
\text { rero, Mexico. }\end{array}$ & & $\begin{array}{l}\text { The sense of the place and its re- } \\
\text { lation with the attitudes and pro- } \\
\text { environmental habits in students. } \\
\text { The case of the Gánale al } \mathrm{CO}_{2} \text { pro- } \\
\text { gram. }\end{array}$ \\
\hline $\begin{array}{l}\text { Effect of water dispersion of arsenic, } \\
\text { cadmium and lead on the quality } \\
\text { of the sediments and surface water } \\
\text { of the San Miguel micro-watershed, } \\
\text { Zimapan. }\end{array}$ & & $\begin{array}{l}\text { The notion of the environment of } \\
\text { girls and boys of } 5 \text { th and } 6 \text { th grade } \\
\text { of primary school in Mexico City and } \\
\text { the City of Oaxaca. }\end{array}$ \\
\hline $\begin{array}{l}\text { Identification and use of nano-waste } \\
\text { generated during the synthesis of } \\
\text { nanomaterials. }\end{array}$ & & \\
\hline $\begin{array}{l}\text { Analysis of the environmental be- } \\
\text { havior of the most commonly used } \\
\text { herbicides in the Rio Tecolutla sub- } \\
\text { basin, Veracruz. Case study: Munic- } \\
\text { ipalities of Tecolutla and Gutiérrez } \\
\text { Zamora. }\end{array}$ & & \\
\hline $\begin{array}{l}\text { Analysis of the carbon footprint and } \\
\text { nutrient content of the nixtamal } \\
\text { mass produced in mills located in } \\
\text { a ZMVM under the GTG model. }\end{array}$ & & \\
\hline $\begin{array}{l}\text { Microbiological characterization of } \\
\text { leachate produced by the Compost } \\
\text { plant of Bordo Poniente. }\end{array}$ & & \\
\hline $\begin{array}{l}\text { Determination of herbicides in envi- } \\
\text { ronmental matrices: soil and water, } \\
\text { in Papantla, Veracruz. }\end{array}$ & & \\
\hline $\begin{array}{l}\text { Evaluation of the digestate gener- } \\
\text { ated by the anaerobic digestion of } \\
\text { the organic fraction of urban solid } \\
\text { waste in Mexico City. }\end{array}$ & & \\
\hline
\end{tabular}


Table 5: Master's Thesis in Science in Environmental and Sustainability Studies Conducted by 2 Areas (source: [17])

\begin{tabular}{|c|c|c|}
\hline \multirow[t]{9}{*}{$\begin{array}{l}\text { and } \\
\text { Engineering }+ \\
\text { Territory and } \\
\text { Environment }\end{array}$} & $\begin{array}{c}\text { Territory and Environment }+ \\
\text { Society and Environmental } \\
\text { Policy }\end{array}$ & $\begin{array}{c}\text { Society and Environmental } \\
\text { Policy }+ \text { Biosciences and } \\
\text { Engineering }\end{array}$ \\
\hline & $\begin{array}{l}\text { Analysis of the impact of Urban Cul- } \\
\text { tural Tourism in the Historic Center, } \\
\text { World Heritage Site of the City of } \\
\text { Puebla de Zaragoza, Mexico. }\end{array}$ & $\begin{array}{l}\text { Ergonomic study of agricultural } \\
\text { practices during the growth and } \\
\text { transplantation of coffee plants. }\end{array}$ \\
\hline & $\begin{array}{l}\text { Evaluation of the urban public poli- } \\
\text { cies of Tecámac de Felipe Villanueva, } \\
\text { State of Mexico for the achievement } \\
\text { of a sustainable urban management. }\end{array}$ & $\begin{array}{l}\text { The relationship between governance } \\
\text { and sustainability in the fishing pro- } \\
\text { duction cooperative society La Plan, } \\
\text { La Encrucijada Biosphere Reserve, } \\
\text { Chiapas, Mexico. }\end{array}$ \\
\hline & $\begin{array}{l}\text { Analysis of consistency evaluations } \\
\text { and results of federal programs sub- } \\
\text { ject to operating rules, case study: } \\
\text { PAL } 2007-2011 \text { clean water program. }\end{array}$ & $\begin{array}{l}\text { Social advertising campaign to en- } \\
\text { courage the separation at the source } \\
\text { of recyclable solid waste for the in- } \\
\text { habitants of the Federal District. }\end{array}$ \\
\hline & $\begin{array}{l}\text { Family farming to sustainable use } \\
\text { of orchids in Xicotepec de Juá rez, } \\
\text { Puebla. }\end{array}$ & $\begin{array}{l}\text { A rehabilitation strategy for aban- } \\
\text { doned tailings dams in the munici- } \\
\text { pality of Zimapán, Hidalgo. }\end{array}$ \\
\hline & $\begin{array}{l}\text { Perception on the green areas of the } \\
\text { residents of the Hipódromo neigh- } \\
\text { borhood, Delegación Cuauhtémoc, } \\
\text { Mexico City. }\end{array}$ & $\begin{array}{l}\text { Socio-ecological diagnosis of the Ar- } \\
\text { royo Peña Gorda watershed, Gus- } \\
\text { tavo A. Madero DF. Elements for } \\
\text { holistic management. }\end{array}$ \\
\hline & & $\begin{array}{l}\text { Use of herbicides and their spatial } \\
\text { distribution in the Rio Tecolutla sub- } \\
\text { account (municipalities: Tecolutla, } \\
\text { Gutiérrez Zamora and Papantla). }\end{array}$ \\
\hline & & $\begin{array}{l}\text { Identification of agrochemical con- } \\
\text { taminants and their relationship } \\
\text { with the socio-economic activities of } \\
\text { the communities surrounding the La- } \\
\text { guna de Santiaguillo watershed, Du- } \\
\text { rango. }\end{array}$ \\
\hline & & $\begin{array}{l}\text { Minamata Agreement and regulation } \\
\text { of mercury in Mexico. }\end{array}$ \\
\hline
\end{tabular}


Table 6: Enrollment in CIIEMAD (source: [17])

\begin{tabular}{|c|c|c|c|c|c|}
\hline Class & Students & Graduated & Drop outs & Current & Graduation $\%$ \\
\hline $\begin{array}{c}\text { I A10 January - } \\
\text { July, } 2010\end{array}$ & 5 & 3 & 2 & & 60 \\
\hline $\begin{array}{l}\text { II B10 August - } \\
\text { December } 2010\end{array}$ & 4 & 3 & 1 & & 75 \\
\hline $\begin{array}{l}\text { III B11 August - } \\
\text { December } 2011\end{array}$ & 13 & 9 & 4 & & 70 \\
\hline $\begin{array}{l}\text { IV B12 August - } \\
\text { December } 2012\end{array}$ & 9 & 7 & 2 & & 78 \\
\hline $\begin{array}{l}\text { V B13 August - } \\
\text { December } 2013\end{array}$ & 20 & 17 & 3 & & 85 \\
\hline $\begin{array}{l}\text { VI B14 August - } \\
\text { December } 2014\end{array}$ & 18 & 14 & 4 & & 78 \\
\hline $\begin{array}{l}\text { VII B15 August - } \\
\text { December } 2015\end{array}$ & 11 & 6 & 1 & 4 & 55 \\
\hline $\begin{array}{l}\text { VIII B16 August - } \\
\text { December } 2016\end{array}$ & 17 & & & 17 & $\begin{array}{c}\text { Graduation in } \\
2018\end{array}$ \\
\hline $\begin{array}{l}\text { IX B17 August - } \\
\text { December } 2017\end{array}$ & 6 & & 2 & 4 & $\begin{array}{c}\text { Graduation in } \\
2019\end{array}$ \\
\hline
\end{tabular}

